\title{
自動定電圧装置について
}

\section{§1 はしがき}

現在では医学分野でも種々な電子装置が広範围に使 用されている. まさにメディカルエレクトロニクス時 代であって, 本稿主題の自動定電王装置もそれ等の装 置に組み込まれたり，あるいけ咐属器として使用され ているが，リニアック，ベータトロンのような大容量 の場合の他は医家が直接の関心を持たれる必要はある まい，しかし，ある程度の参考といらこともあるので 一般的な説明を試みることにする.

\section{§ 2 自動定電圧装置とはどんなものか}

正式の名称は需用端自動電圧調整器であるが，定電 圧装置, 自動電圧調整器, AVR, スタビライザー, レ ギュレーターなど，いろいろな呼ばれ方をしている. これは商用電源の電圧の変動を吸収して常時規定の值 に保つための装置である. 電力会社の努力によって， 今では本質的には供給される電力の質はかなり改善さ れているが，それでも一部の地区では問題があるし， 電力会社の責任でない電圧変動もある。たとえば冷蔵 庫や井戸ポンプが起動する時に瞬時電灯が暗くなるこ とは一般に経験されるところである，良い例ではない が酸素ボンベの減圧器や, テープレコーダーの自動音 量調整器等と類似した作用のものである. 前者の例で は, 減圧器は気温, ガス残量, ガスの流量等にかかわ らず吐出側のガス圧力を一定に保ち，後者の例では録 音す心゙き音が強くなっても弱くなってもテープには， ほぼ一定の強さで録音されるように作用する，減圧器 の例では，入口側の圧すは必ず出口側より高いが，定 電圧装置の場合は入口側（入力または一次側といら） の電圧が出口側（出力, 二次側等という）より低い場 合もあり，この場合には昇圧しなければならない。

筆者の知る限りでは，定電圧装置が商品として日本 で生産されたのは，第二次大戦直前に東芝から鉄共振 型のものが発売されたのが最初である. つづいてVOLCO その他二，三の業者が製造を始めた。 戦後の一 時期，いわゆるローソク送電時代に小ブームがあった が，これはあとで説明する理由であまり役に立たなか ったことと, 電力事情が急速に改善されたことによっ てすぐに消滅した．昭和 20 年代の後期にもう少し真面

*日本電源機器株式会社取締役技術部長
目な観点から検討された本質的な自動定電圧装置が, ポツポッとあらわれ出し，筆者の会社から昭和 29 年に 真空管型, 昭和 26 年に磁気増幅器型, さらに35年には トランジスタ型が発表され，今ではもらボン心゙の減压 器やテープレコーダーの自動音量調節器のようにポピ ュラーで地味なものになっている.

\section{$\S 3$ 自動定電圧装置の使用目的}

今，述べたような地味な品物であるから，“なぜな らそれがあるから”といらような理由で使われるべき ではない，良心的な業者にとってはこれでは「ひいき の引きたおし」であろう，定電圧装置には，使用する 必要がまったく無いか，または使用が有害である場合 と，使用によりある程度改善される場合，そして使用 が不可欠な場合とがある.このことはメディカルな用 途に限らず一般的なことである.

まず電気をエネルギー源，特に動力用に使用される 場合注電力会社によって供給される電圧が相当変動し ても特別の不都合はまず起こらないと見てよい。たと えば, 吸引器, 空調機, 整形外科用機械のごとく, 主 としてモートルが主役になっているものに対しては, 定電圧装置を使用する必要はまず無いといって良かろ 5. 単なる照明用, 電熱用の電力も同様であろう. 電 㽵変動（主として電圧降下）によって障害が起こるよ らであれば，電力会社のサービスステーションに申し 入れて, 電力供給規定どおりの常識的な品質の電力が 供給されるように改善してもららべきである.この場 合には，原則として費用はかからない.大規模な病院 で高圧受電を行なっているところでは，申し入れの相 手が営䋛課とか電力係であることもあろう．地区や所 内の事情によっては直ちに改良されない場合もあろう が，供給される電圧が20\%以上も低い場所では，定電 圧装置を使用して，これを改善しようというのは邪道 であるばかりでなく無効である場合もある，というの は，一般的な電気装置では，電力は電圧の二乗に比例 するもので, 正規 $100 \mathrm{~V}$ の電圧で $1 \mathrm{KW}$ の電力を消費 するものに $80 \mathrm{~V}$ しかかからないと，電力は $640 \mathrm{~W} に$ 低下し電流も $8 \mathrm{~A}$ になる，ところが，これを定電圧装 置によって正しく $100 \mathrm{~V}$ に修正して使用すれば， $80 \mathrm{~V}$ の電圧から $1 \mathrm{KW}$ 電力を供給することになり，定電 圧装置の損失を零とした理想的な場合でも，電流は 
$12.5 \mathrm{~A}$ 流れなければならない。これは定電圧装置を使 用しなかった場合の $8 \mathrm{~A}$ に比較すると実に $60 \%$ 近く の増加となり電圧降下は，さらに増加するであろう。 定電圧装置が正しく動作している限り，この結果上記 の理由で電流はもっと増加し電源電圧は，またまた降 下寸るという悪循環になるおそれがある．この種の最 悪の場合には非緊急の機器の使用を一時停止して負荷 を減少させることと，重点的に必要なものに，なるべ く小容量の定電王装置を使用することだけが対策であ る. 現在，正常時の郘会地，陸上といら条件でこんな ことを本気で心配していると神経科の彰断を勧告され るおそれもあるが，条件がいつも成立寸るとは限らな いし，同一給電区域が同一の人間の管理下にあるとも 限らないから，医陑として必要を認めた場合は近隣の 協力を求めることもあり得るであろう。

第二の場合は, 恒温槽, 恒温乾燥器, 定温電気炉, レントゲンフィルム等の自動現像器等の場合である。 これらの装置は，通常必要な量を自動調節する機能を 内蔵している場合が多く，通常定電圧装置がなくても 使用できる。しかし，もし使用すると，装置本体の調 節機構の負担が軽くなるので，その分だけ改善された 結果が期待されよう。これらの場合は, 改善率をどう 評価するかが問題で，主観的要素が判断の基礎にな る.たとえば，電気入不恃筆者のごとき電気技術者の 立場からいえば，電源変動に特に神経質になる必要の ない機種であるが，手術というような緊張した作業を 行なら外科医などは人によっては最高級の定電圧装置 を使用して，メスの調子や使い具合を徹底的に一定に することを望むかもわからない．……筆者は医学につ いては門外漢であるから何ともいえないが…...

第三の使用分野は，電圧そのものが測定や制御の基 準になる場合である．ある種の分光光度計（紫外，赤 外，可視を問わず）では，電圧一光量——測定值と 直接に結びつき，測定值は電圧のほぼ 5 乗に比例す る. 放射線関係の分析でも電圧一線量または硬さ 一測定值と直接に関係する.ある種のガス分析計， 電気泳動装置，水分計等も被測定量と測定指示值との 物理的関係に電圧の n 乗が係数として含まれる場合が 多い, $\mathrm{n} か ゙$ 充分小さいか, 電圧值を含む項が他のものに 比較して小さい場合は別として，原則的に定電圧装置 は不可久のものになる. 質量分析装置, 核磁気共鳴装 置等もこれに属するであろう。その他シンチレーショ ンスペクトロメータ，ガンマ線波高分析計, $\mathrm{pH}$ 計, ク ロマトグラフ，脳波訳，電子顕微鏡，ラジオカプセル 受信器等には誤差が電王の変動に対して鋭敏なものが 多く，定電圧装置はなるべく使用すべきものである.

\section{§ 4 自動定電圧装置の原理}

先にも述べた通り今日では，定電压装置はポピュラ 一な品物で，商品としての信頼性を別とすれば，これ を企画製造することは，さして困難な仕事ではなく， メディカルエレクトロニクス装置の企画製造と比較す れば，はるかに容易な作業である（ただし決して安易 な作業ではない，念のため)，これは要するに自動制 御技術のごくせまい一分野……すなわち, 電圧の定傎 制御といら分野である.この種の装置は少数の例外を 除くと, 検出部, 基集量, 調節増幅器, 操作部から構 成されている，操作部とは，定電圧装置の場合であれ ば，電圧を上げたり下げたり任意に操作できる装置で あって，たとえばスライダックのようなものである. 現にスライダックやその類似品は, 誘導電圧調整器等 とならんで機械式定電压装置に使用されている。 しか し, 今では性能を重視する場合には静止型の純電気的 に作動するものが好まれる，目下のところ，その主流 となっているのは可飽和リアクトルと称せられるもの で, 超精密を目標とする時は真空管やトランジスタ等 も使用される. 小容量の直流定電圧装置の場合は, 卜 ランジスタが主力になる．问飽和リアクトルというの は電気鉄板（数\%の珠素を含んだ鉄を特別な工程で製 造したもの) で作られた鉄心と，これを電流により磁 化するためのコイル(銅線を巻いて作ったもの)とを， ある特定の組合わせで構成した簡単な装置で, 信号コ イルと通常称せられる一組のコイルに值流の電流を流 寸と, 交流巻線と称せられるもう一組のコイルのイン ピーダンス（電流阻止力）が大きく変化する性質をも っている. この可飽和リアクトルを使用すると, 小さ な直流の電力で大きな電力の交流の電圧を㕕範囲に操 作することができる．可飽和リアクトルそのもの，ま たは，これにいくつかの補助手段を追加して性能を向 上させたものは磁気增幅器とも呼ばれる.

また SCR (シリコン制御整流素子)，SSS，GTO， トライアック等ヶ一連の半導体素子も, 一部は相当程 度，また一部は試験的に使用され，価格と大きさ，重 量等の点で有望な将来性をもっている。・

調節増幅器は, 上記の操作部分を, 出力電圧が一定 の值になるように調節する部分であって，通常は増幅 器であるが, 此較的低性能, 低コストをねらって操作 部にスライダック, 誘導電圧調整器等の機械的なもの を使った場合には，単なるリレーで用が足りることも ある.これの断続逆転により，モートルを正転，逆 転, 停止させ, スライダック等を調節するのである.

基準量というのは出力が一定值になっているか否か を比較判断するための物差に相当するもので, 当然一 定の值をもっていなければならない，定電圧装置では 
一定の電圧または電流を基準とする場合が大部分で, これを得る手段としては定電圧ダイオード，定電圧放 電管, 定電流安定抵抗管, 鉄心》飽和現象を利用した 装置等の部品が使用される．また使用法によっては必 ずしも一定の值を持たなくとも非直線的な性質さえあ れば良いこともある（他の非直線的なもの，または直 線的なものとの交点に相当する点が一定であれば...).

検出装置 上に説明した基準量は，いずれも直流の 電圧や電流だから，出力が交流の電圧である場合は， 直接これと比較することができない，また直流であっ てもその值が基準量と同一とは限らないし，理論的に は基準量が電気的なものでなければならないわけでも ないので, なんらかの形で出力を基準量と同じ性質で ほぼ同じ值の量に変換しなければ比較ができない.こ の変換を行ならのが検出部で, 抵抗分圧器だけの場合 もあり, 整流器で交流直流変換を行なら場合もあり,

二極管の熱電子電流, 熱電対, 小型ランプと光電管等 々いろいろの方式が使用されているが，これらは基準 量と出力との性質や設計者の判断等と関係するもの で，どれでなければならないといった決定的なものが あるわけではない。

さて,これらの諸要素を第 1 罒のように組み合わせ て次のような動作を行なわせる. まず出力電压を検出 装置によって変換し，これを基淮量と比較する．検出 されたものも基準量も直流電压であれば，たとえば両 者を逆向值列に接続すれば両者の差が得られる。

基準量が電圧であれば基淮電圧といい, 基準電压と 検出電压との差を䛊差電圧等という.この誤差電圧を 調節増幅器で増幅して操作部分に加えるのである.

たとえば操作部が前述の可飽和リアクトルであれば 信号コイルの端子に接続するなどである.この場合, 接続の向きを，出力電压が上昇した場合に誤差電圧が

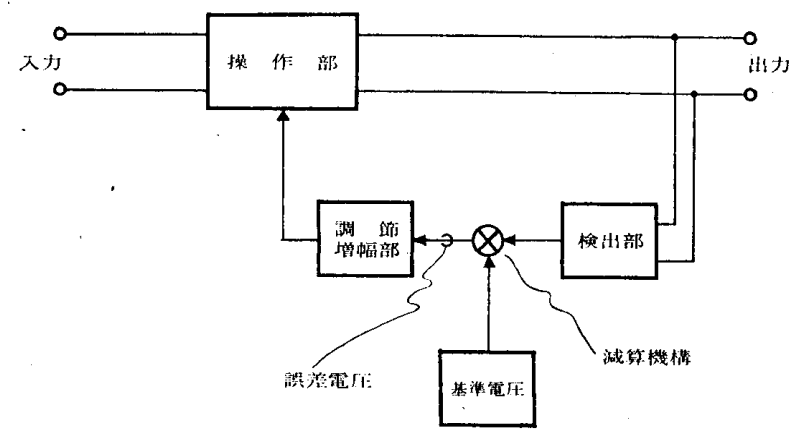

第 1 図 定電圧装置の回路構成

操作部分に対し引き下げるような順序に組み合わせる ことが必要であり,このように組み合わせて置けば, もしなんらかの理由（たとえば入力電圧の変化，負荷 の変化等）で出力電圧が変化すると，この一組の系は
その変動を減殺するように動作することは明らかであ ろう. その作用は調節増幅器等の利得（どのくらい微 少な誤差電圧により, どのくらい強力に操作部をらご かし得るかの程度）によって決定される。

\section{$\S 5$ 定電圧装置の種類と得失}

種類といら場合，一般的になにを基礎にして分類す るかによっていくつもの考え方があり得るわけである が, ここでは専門家にしかられるのを覚悟の上で, 前 章で使った各要素により，実用的な立場で説明する.

電気には，ご承知のごとく直流と交流がある。交流 の場合の周波数は通常の商用電源では，ほぼ一定に決 まっているために考えないで良いが，例外的には問題 になることもある．まず入力側の条件が直流か，交流 単相か交流三相かによって三種類になろう. 出力側も 同様である，操作部については，これが機械的な可動 部分を含むか，静止型の電気的なものかに分けられ る.しかし，この調子で説明して行くと大へんなこと になるので，二覧表の形にすると第 1 表のようにな り，この組み合わせだけで何百といら数になるが，実 際に工業製品として供給されているものは，ごく少数 である. 入力あるいは出力が直流のものは基礎研究室 以外では医学関係者が単独に購入使用されることは, まず無いと思われるので，例だけあげて説明は省略す る.

第 2 図のもの懆作部, 調節部共トランジス夕、基 準電压に定電压ダイオードを使った小容量の直流安定 化電源で，第 3 図はカタログから抜き出した回路説明 図である、第 4 図は同じく淔流出力の大容量器で, 入 力側は三相交流, 操作部には SCR が使用されてい る. この種の超大型のものは電話, 鉄道, 化学工業等 の専門技術者以外にはあまり関係のないものである.

鉄共振型定電圧装置 これは前章の説明で少数の例 外といったものの一つで, 鉄の磁気的飽和による鉄共 振現象を值接利用した交流用のものであり，ある電気 的構成と条件の下では，一つの物理現象として定電压 特性を持っているものである．応答速度がきわめて早 いといら本質的な特長を有する反面, 出力波形が悪 く，電源周波数の影響を受けるという久点も本質的な ものである. しかし現在では, 電源周波数が充分安定 化されているので，正しく設計されたものは波形ひず みも特に悪くはなく, 簡単, 堅牢, 保守不要等の特長 のため使いやすい便利なものである. 第 5 図, 第 6 図 に一例を示す.この種のものは物理現象を生のまま使 ら関係で微細な調節ができないので, 安定度は大体に おいて $1 \%$ 前後である.

機械式定電圧装置 スライダック, 摺動変圧器, 誘 導電圧調整器等をモートルと組み合わせて操作部とし 


\section{第 1 表 定電 圧 装 置 の 分類}

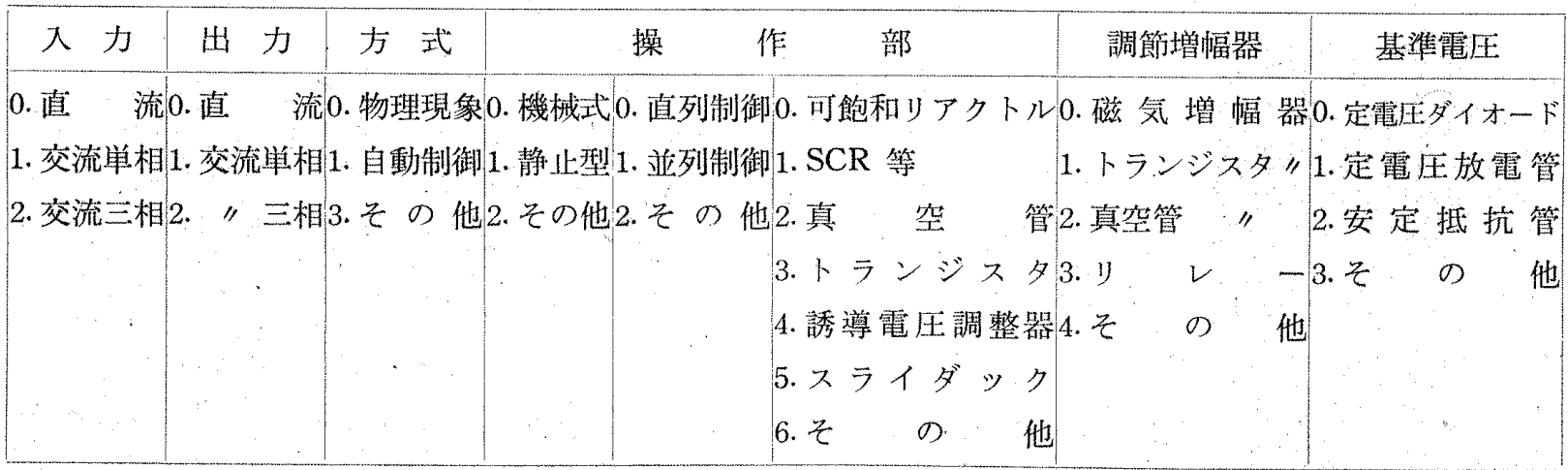

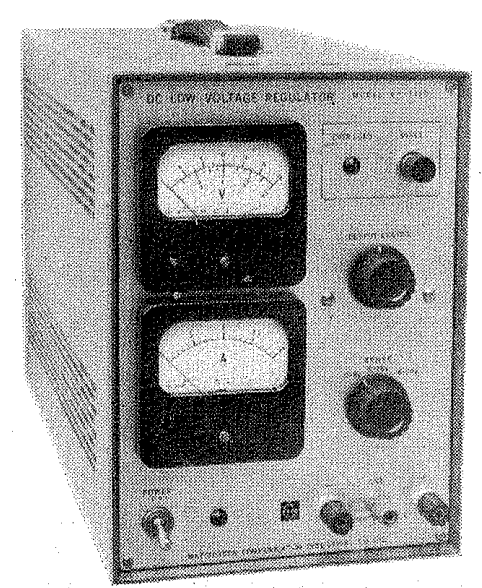

第 2 図小容鱆直流定電圧装置 電厓 $0 \sim 24 \mathrm{~V}$, 電流最大 $2 \mathrm{~A}$ （松下通信工業製）

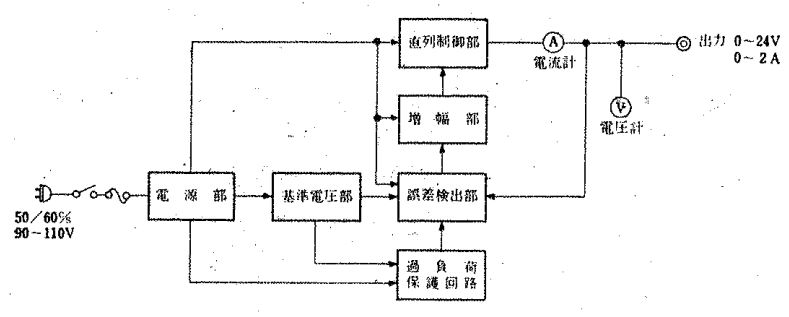

第 3 図 第 2 図の回路構成

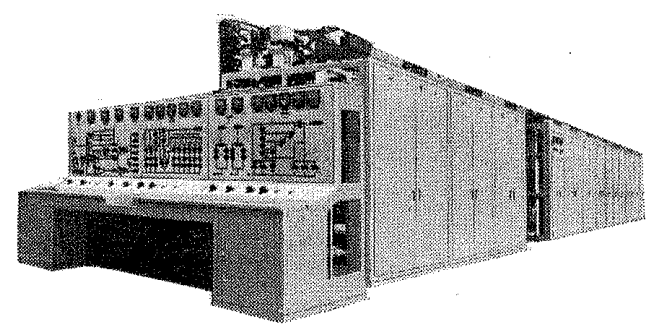

第 4 図大容睹直流電源 $48 \mathrm{~V}, 10,000 \mathrm{~A}$ (新電元工密製)

たもので，容量が大きくなると価格が割安になるこ と，電圧波形にひずみを追加しないこと，短時間過負 荷に強い等の特長がある，応答を早くするため空気压
で操作する試みもあるが，奉命との関係からあまり早 くはできにくいこと，可動部分があるので，ある程度 の保守注必要であること等が短所である、照明，動 力, 雪熱等の大容量の雑用定電圧装置しして性利で あるら

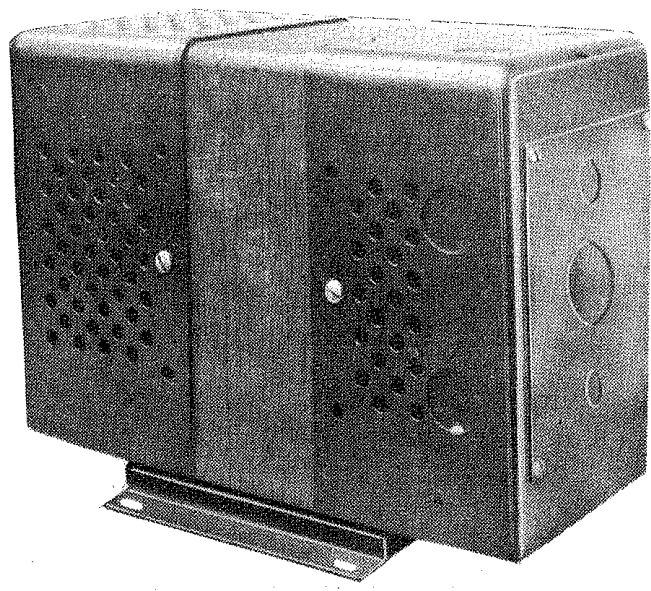

第 5 図小容䁪鉄共振型定電在装遗 118 V. $250 \mathrm{~W}$

(米国 SOLA 社製)

静止型定電圧装置 機械的に運動する部分を含まな いものをいう．先に説明した鉄共振型も静止型である が，ここでは第四章で説明した自動制御方式のものに 限定する，現実に存在するものは，ほとんどが操作部 に可飽和リアクトル, 調節部に磁気増幅器, トランジ ス夕増幅器, 真空管増幅器のどれかを組み合わせたも ので, 堌幅器の種類によって磁気增幅器型とかトラン ジスタ型等と呼ばれることが多い.最近では増幅器を どれにです差しかえて使える万能型と称寸る若干進歩 したものが主流になっている，第 7 図がそれである.

実際に注どの組み合わせも，それぞれの特長と短所 はあり得るが，現在の技術水準では，適切に設計され ていれ代実用上大差はないただ非常に高い精度を期 待される場合には真空管型，信頼性に重点をおく場合 は磁気增幅器型が推奖できよう. トランジスタ型は, 大体その中間である. 操作部の可変要素（可飽和リア 


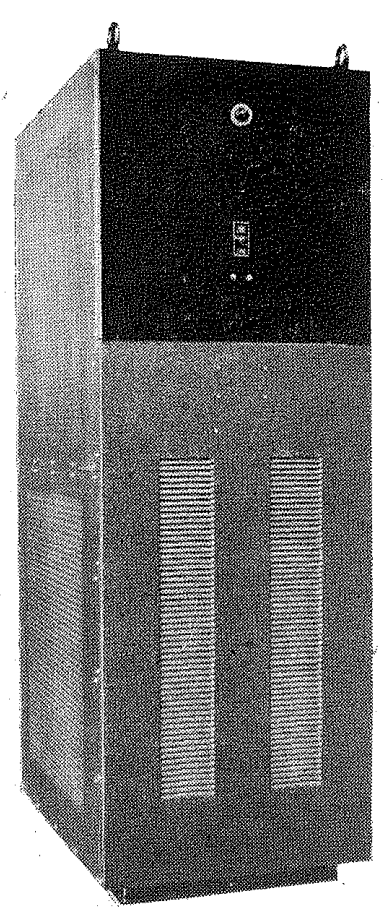

第 6 図大容量鉄共振型 定電在装置 200 V. $6.5 \mathrm{KVA}$ (VOLCO 製)
クトル等）が電気回路的 に負荷亡直列に，乙う人 されたものと, 並列に使 用されるものとがある が，傎何力率が卧い場合 や電源そのものの波形ひ ず夕が多い場合，三相用 の場合等に海者の並列 操作方式が有利である。

半尊体静止型定電压装 置 操作部が SCR その 他の新しい半導体素子の もので,この場合調節部 の方品つり合い上トラン ジタ等の半導体のもの が多い，特長の方は先に 述べたが，本質的な欠点 は波形ひず办良くしが たい点である。挌てらく 未来の定電圧装置の主流 となると思われるが，現

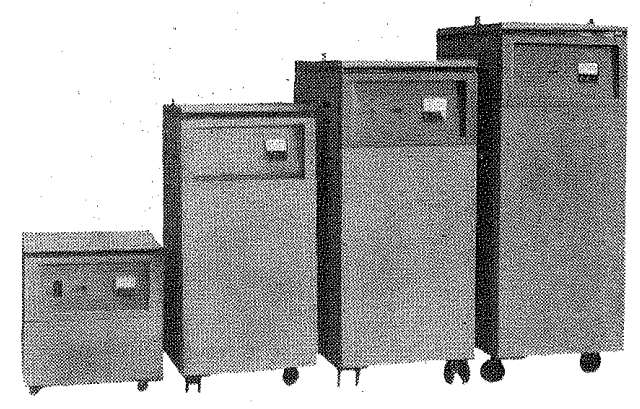

第 7 図 万能型定電圧装置 $2.5,4,6.5$, $10 \mathrm{KVA} 4$ 種類 (VOLCO 製)

在の上ころでは，これらの半導体そのものが，す心゙て の使用条件での充分な信頼性をもつかどうかといら疑 点定残している。半導体グループのらら一番歴史の占 いSCR は，使用条件がほぼ一定になる直流用の定電 压装置には現在でも相当例使用されている。なおこ れらの新素子を使用すると答が早くなるといらの は，自動制御理論からいえば，原則として無意味， あるいは間違いである。

その他，操作部に真空管やトランジス夕を使ったも のもあり，慎重な設計の下では警基的な高性能を発揮 する，この場合，基隻量注同位相の純正弦波電压が使 われる、第 8 罒がその例である。

\section{§. 6 . 使用上の注意}

以上の説明で定電压装置がどんなものでめり，電気
技術の中でどんな地位定占めるかについて，大体のイ メージ玨解していただけたと思ら。

要するにそそ扎はモートルやトランスよりいくらか 複雑な，そして大部分のメディカルエレクトロニタス に比較すれば，はるかに鉴純な一種の電気機械であ る、医家に扔ける使用上の注慧嘈項としては，大体王 ートル，下ランスなみの次の二点かと思われる。

すな⿰ら口，麻酔室等の懪発性ガスの女る所ではケ全 の策党施して使用すること，文び脳没計宝のごとき電 気的にシールドされた窒で使用する場合に㳸洩磁束等 の影響孝あらかじめ調查寸ること等であるら。

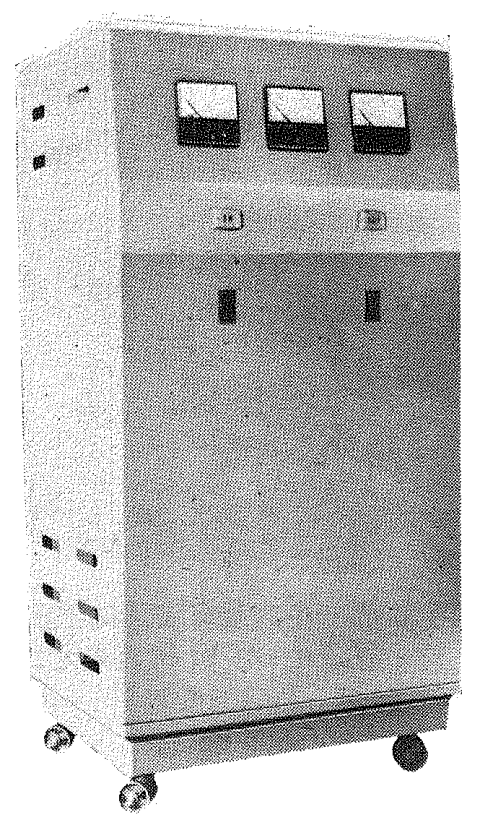

第 8 図 全真空管型高性能 定電圧装置 $100 \mathrm{~V} .1 \mathrm{KVA}$ (VOLCO 製)

$\S 7$ 終りに

編輯者が筆者に期街したのは，お厹らく正確な諭文 式のものではなく，メディカルエレクトロニクス時代 の医家の常識程膺の解説であったるら，そこで筆者は 正確堂無視して「わかったよらな気の寸る」ムード的 解説に努力したつもりであるが，不出来の点泩括沛る し願いたい，东た，術語の類も故意に正確老無視して 直観的なものを使ってある。

最後にもし読者が定電压装置を購人される立場にな ったとしたら，いくら自信があるとは、气，記事欄で 篗者の会社の宣伝をするわけにも行かず，その選执の 最良の方法は諘者がドクターであられる点を活用され て，セールスマンや技術者を問診され，そのレバルを 判断されることであるら。 